\title{
Umělecké dílo jako spolutvůrce (literární) teorie
}

MNICH, L.: Шекспир в русской теории первой половины ХХ века. Siedlce: Uniwersytet Przyrodniczo-Humanistyczny w Siedlcach, Instytut Polonistyki i Neofilologii, 2019.

Ludmila Mnich(ová) je respektovanou odbornicí ve sféře literární vědy a zejména literární teorie, která se specializuje na ruský literární vývoj a ruskou literární vědu, především na modernu a obecně její poetiku (speciálně symbol a symbolismus). Její badatelská kariéra se započala v Drohobyči a byla spjata i s jiným ukrajinskými badatelskými centry (Doněck): později přešla na tehdy nově založenou Akademii v Podlesí v Siedlcích (Akademia Podlaska v Siedlcach, později univerzita, „zadní dvorek" Varšavy a postupně se formující vědecké centrum v oblasti slavistiky, které zastínilo - alespoň ještě nedávno a ve slavistice a literární vědě obecně - mnohé tzv. „kamenné“, tj. zavedené, tradiční polské univerzity): zde Ludmila Mnichová přednášela jako v podstatě docentka rusistiku a anglistiku, zabývala se literární komparatistikou, což přirozeně vyplynulo z jejího víceoborového zakotvení (rusistika, ukrajinistika, polonistika, anglistika). Napsala za poměrně krátkou dobu více než 50 studií, které se pohybují na hraně symbolistické poetiky (literárněvědná numerologie, intertextualita Bible nebo Božské komedie, problémy aplikované hermeneutiky, symbolismu, akméismu, imažinismu, zejména Velimir Chlebnikov a Anna Achmatovová). Rozsah jejího odborného záběru je vskutku široký a zasahuje i ruské poezie novější doby (mj. Bella Achmadulinová), ale byla vtažena i do projektů metodologicko-filozofických od rusistické literární lexikografie (Andrzej de Lazari) až ke komeniologii, oboru, jenž - možná na rozdíl od českého prostředí - v posledních dvaceti třiceti letech takřka masově zachvátil Polsko a Německo. Nezanevřela ani na čistě rusistickou a ukrajinistickou literární vědu (V. Šklovskij, Dmytro Čyževs'kyj). Tíhnutí k hraničním jevům se podepsalo i na její malé monografii o Veronice Dolinové. ${ }^{1} \mathrm{O}$ jedné její knížce jsem už psal. ${ }^{2} \mathrm{Na}$ počátku se v malé retrospektivě k její dosavadní tvorbě jako předdveří knihy o Shakespearovi v ruské teorii vrátím.

Její numerologická kniha se svým názvem, citátem z Dostojevského novely ze 40. let 19. století Polzunkov vrací k tradici číselné symboliky, jež má své hlubinné kořeny. Význam čísla znamená jít opravdu hluboko do minulosti, do života prvních nám dosud známých despocií; zejména nám tu pomůže hebraistika, starozákonní

1 Viz její monografie [MNICH 2016a; $\mathrm{MNICH}$ 2016b]; vyvrcholením je reprezentativní recenzovaná publikace [MNICH 2019].

2 Viz [POSPÍŠIL 2017]. 
Genesis, kam se táhne i tzv. staroruská inspirace, jež však tuto tradici reflektuje jen fragmentárně. A ty moderní koncepce typu Ernsta Cassirera nebo Pavla Florenského představují minimálně sekundární reflexi použitou asi tak, jako když H.-G. Gadamer navazoval na starověkou a středověkou hermeneutiku. Mnichová správně analyzuje estetiku a filozofii numerického symbolismu, jinak řečeno to, co se z pủvodního čísla jako počátku a základu všehomíra využívalo od středověku a renesance dál, tedy zkoumá numerickou hodnotu symbolu jako součást motiviky a poetiky artefaktu. Opírá se přitom o symbolologii 20. století v podání Cassirera, Averinceva, Loseva, Toporova aj., tedy především z německo-americko-ruského okruhu, i když by se nabízely i možnosti jiné. Klíčovým akordem díla je analýza poezie Anny Achmatovové, kde se ukazuje, že prakticky v každé její básni jsou symbolické obrazy, které spolu interagují, mj. symbolika čísel 30, 13, 9, 4, a 6. Určitá stř́ídmost, střízlivost, v tomto tématu poměrně vzácná, tu připomíná podobné postupy českého literárního kritika, historika a teoretika Milana Blahynky, jenž takto analyzoval románovou tvorbu Milana Kundery [BLAHYNKA 2019]. Zejména v dílčí studii Magie jmen, čísel a prvočísel, kde se jedná především o románu Nesmrtelnost Blahynka ukazuje na rafinovanou číselnou stavbu Kunderových próz. V triptychu Třikrát Milan Kundera demonstroval i to, že českost romanopisce nemizí, ani když píše jiným jazykem, např. na románech Pomalost (La Lenteur, 1995) a Setkání (Une Recontre, 2009). Podobně se zabývá Zrazenými testamenty/závětmi. Reflexe $M$. K. Čechořipský de la douce France, která vyšla v brněnském Hostu roku 1996 a byla dedikována Jiřímu Veselskému, pracuje v souvislosti s Pomalostí s magii čísel, ale také jmen. Blahynkovo hledání trvalých stop a úchytných bodů $\mathrm{v}$ Kunderově díle tu pokračuje. Vyjadřuje to mimo jiné takto: „Kunderovy knihy jsou do značné míry všechny Žertem, všechny Směšnými láskami, všechny zahradou širou a všechny - už také - psány tak, aby se musely číst zvolna - také Pomalostíi [BLAHYNKA 2019, 160]. Poslední sedmá (příznačně!) studie souboru je stará jen několik let (LUK 2014) a soustředí se na Kunderův zatím poslední román Oslava bezvýznamnosti [KUNDERA 2014]. Snad tato poměrně rozsáhlá odbočka upozorňující na možnost plodné komparace dvou badatelských př́stupů funkčně uvozuje hloubkovost - i když pomineme podobně interpretačně podnětnou knihu o Veronice Dolinové (roč. 1956) - její knihy o Shakespearovi v ruské teorii. Monografie představuje skvělý př́klad kompaktního a komplexního výzkumu holistické významnosti díla světového dramatika pro ruský duchovní a kulturní život. Autorka nemůže přirozeně ignorovat celý historický proces Shakespearovy recepce v Rusku, ale její dílo není pouhou analýzou recepčního procesu, ale všeobjímajícího Shakespearova působení na ruskou teorii jako takovou. Hlavní předpoklady autorka analyzuje v první kapitole, v níž se zabývá shakespearovským diskurzem v ruské

Viz naši recenzi [POSPÍŠIL 2019b]. 
teorii a tzv. západní shakespearologií. Pokud však Západ v jejím chápání není jen západní Evropa, překvapuje fakt, že tu není ani zmínky o stř̌edoevropském myšlení o Shakespearovi. Ludmila Mnichová jmenuje několik ruských badatelů, kteří se dramatikem a básníkem zabývali, a jeho vlivem na ruskou teorii; teorie není v tomto pojetí, jímž se autorka inspiruje ruskými teoretiky, jen teorie literatury, je to způsob obecného myšlení a obecných představ a obrazů tvořících ruský svět ${ }^{4}$ a jeho reprezentanty, jako byli Alexandr Smirnov, Alexandr Anikst, Lev Šestov, Semjon Vengerov, filmoví režiséři a herci, jež se podíleli na utváření Shakespearova image v umění a také v obecné teorii, jako byli Roman Jakobson, Michail Bachtin, Nikolaj Berdajev, Semjon Frank, Viktor Šklovskij, Olga Frejdenbergová, Pavel Florenskij, Aleksej Losev aj. - všichni tvořící v souvislostech tzv. západního filozofického myšlení spolu se jmény Michela Foucaulta, Rolanda Barthese, Jacquese Derridy aj. ${ }^{5}$ Najdeme tu také zmínky o „sovětizaci“ Shakespeara kontaminovaného teorií socialistického realismu a hlavně jeho praxí; v tomto kontextu je jen škoda, že se autorka nezmínila o českém marxistickém kritikovi Bedřichu Václavkovi (1897-1943), posuzovateli avantgardní české poezie a prózy (proletářská poezie, poetismus, surrealismus), který $\mathrm{v}$ polovině 30. let 20. století formuloval mnohem flexibilnější teorii tohoto uměleckého směru - oproti M. Gorkému i známému referátu N. Bucharina - jako syntézy moderny, avantgardy a realismu na materiálu české literatury 20 . století v knize, jež poprvé vyšla $1934{ }^{6}$

Autorka dělí problematiku této kapitoly v rámci daného diskurzu na artikulaci, objektivizaci vědomí diskurzu a - last but not least - dominanci socio-kulturní tradice. Nemohu plně souhlasit s poněkud promiskuitním užíváním slova „vliv“ („влияние“), jež bylo už v dávné minulosti (1979) odmítnuto a dokonce „zakázáno“ v diskusi na stránkách slovenské literárněvědné revue Slavica Slovaca D. Ďurišinem a později všeobecně přijato, hlavně komparatisty „třetího světa“, jako pojem neakceptovatelně mechanistický. Zdá se, že Shakespeare v ruské teorii funguje jako lakmusový papírek vnitřního ruského vývoje. Dokonce se tu zmiňuje i šokující kritika Lva Tolstého, v níž velký romanopisec pokládá Shakespeara na materiálu Krále Leara za tuctového dramatika [TOLSTOJ 1907]: zvláště tato skutečnost bez ohledu na její faktickou hodnotu odhaluje často neprůhlednou clonu pokrývající celý proces toho, jak se

4 Viz [ZENKIN 2004].

5 Возвращаясяь к вопросу о русской теории XX века, отметим, что определенные ее пласты только сегодня получают научное освещение. Современная западная научная мысль в лице видных своих интеллектулов во многом воспринимает Россию прошлого века сквозь призму классиков русского литературоведения - Михаила Бахтина, Дмитрия Лихачева, Алексея Лосева. Однако, с другой стороны, для западного понимания России и русских очень важным является также и опыт русской религиозной философии.“ [MNICH 2019, 22].

6 [VÁCLAVEK 1934]. 1. vyd. vlastním nákladem, Praha 1934, 2. vyd. Vl. Orel, Praha 1935, 3. vyd. Svoboda, Praha 1947, 4. vyd. Čs. spisovatel, Praha 1974. 
z řadového alžbětínského dramatika stala součást světového dramatického a obecně literárního kánonu. Jak to kdysi komentoval George Orwell (Eric Blair): snad je Tolstého sžíravá kritika Shakespeara a jeho Krále Leara projevem závisti velkého Rusa $^{7}$, ale právě reakce 20 . století svědčí spíše o tom, že jde o velmi delikátní, citlivou a zraňující otázku. Na druhé straně je pravda, že v Rusku byl Shakespeare často redukován na několik dramatických postav (Hamlet, Othelo, král Lear), snad ještě na několik postav historických her. Tato redukce a umělé „zfilozofičtění“ Shakespeara se paradoxně týká i ruských formalistů, i když v př́padě Borise Ejchenbauma, jenž svou vědeckou kariéru zahájil jako filozof literatury analýzou N. M. Karamzina, je to pochopitelnější. Tolstojovská označení Shakespeara jako dramatika bez Boha, jako vyjadřovatele kultu výkonu a úspěchu neodpovídá koncepci náboženského, duchovního a kontemplativního myslitele nebo dokonce filozofa. Když jde o uchopení postavy Shakespeara $\mathrm{v}$ ruské teorii, nelze pominout ten největší posun důrazu, který se odehrál v evropské kultuře 17. století: po třicetileté válce na celém kontinentu, po válce krále a parlamentu v Anglii a po ruské smutě se zjevil zcela jiný člověk, jenž změnil Shakespearovo dramatické a básnické dědictví tím, že povlovně odstraňoval nit spojující ho s jeho historickým prostorem a časem. Od té doby tu zbyla jen hra se slova a jejich adaptace na určité poměry a umělecké a myšlenkové vkusy. Od klasicismu se proměnil na model, jenž má být následován, a objevily se shluky interpretací, takže Shakespeare, který se zde stal předmětem všeobecného zbožňování, je víceméně produktem pozdějši estetiky a dobového myšlení.

V další kapitole autorka poněkud štěpí svůj předmět - i když on stále zůstává komunikační plochou - komplementární jednotkou, jež monitoruje různé aspekty hlavního tématu Shakespeare v ruském filozoficko-náboženském myšlení stř́íbrného věku v estetice a literární kritice nebo axiologii ruského symbolismu, dále Shakespeare v koncepci ruských formalistů a závěrečné partie jako vyústění. Zdůraznil bych poněkud menší přesnost zmiňovaných pojmů: bud mluvíme o literárních směrech, nebo o metodologii literární vědy. Když připustíme, že existovala symbolistická kritika/literární věda, mohli bychom také mluvit o kritice futuristické, akméistické a imažinistické a snad i o jiných „kritikách“, ale to by podle mého názoru nebylo homogenní. I když je autorka velmi přesvědčivá právě ve spojování a prolínání heterogenního materiálu, něco odlišného tu přece jen zůstává jako další badatelská možnost. Autorčina monografie je výsostnou prací komparatistickou, i když to zde není nijak zdůrazněno, ale také genologickou a poetologickou, jež tvoří podle mého názoru skutečné jádro výzkumu a má přesahy $\mathrm{k}$ myšlení a filozofii, stejně jako k náboženství a kultuře, tedy k religionistice, teologii a kulturologii. Se znalostí toho podstatného, co

7 [POSPÍŠIL 1992]. Viz dále naše studie a recenzi: [POSPÍŠIL 1993; POSPÍŠIL 2010; POSPÍŠIL 2019a; POSPÍŠIL 2019c]. 
Ludmila Mnichová už napsala, lze ř́íci, že tato kniha je určitou syntetizující etapou její dosavadní vědecké činnosti (viz výše), v níž kvalitativně nově shrnula své dosavadní výzkumy na poli poetiky, literárních směrů a pronikání do nitra ruské literatury jako estetického systému a rezervoáru teoretických reflexí.

Ivo Pospišil

\section{Bibliografie:}

BLAHYNKA, M. (2019): Sedm kapitol o díle Milana Kundery. Křenovice.

KUNDERA, M. (2014): La fête de l'insignifiance: roman. Paris.

MNICH, L. (2016a): «Poèt - u dreva vremeni otrostok...»: poètika i simvolika tekstov Veroniki Dolinoj. Siedlce.

MNICH, L. (2016b): «Zamet'te čislo, gospoda...»: čislovoj simvolizm v russkoj poèzii XX veka. Opuscula Slavica Sedlcensia; tom IX. Siedlce.

MNICH, L. (2019): Šekspir v russkoj teorii pervoj poloviny XX veka. Siedlce.

POSPÍŠIL, I. (1992): Shakespeare, Tolstoj a Orwell. Lidová demokracie 11. 3., 1992, s. 10. POSPÍŠIL, I. (1993): Individualita a proud: Lev Tolstoj a ruská moderna. In: Problémy ruskej moderny. Nitra, s. 95-103.

POSPÍŠIL, I. (2010): Double Réfraction. La mort de Tolstoj en Bohème et en Moravie. Revue des Études slaves LXXXI, (2010), fascicule 1, Tolstoï 1910. Échos. Résonances. Interprétations, s. 53-70.

POSPÍŠIL, I. (2017): Dvě publikace o symbolu a symbolice. Novaja rusistika 2017, č. 1, s. 95-97.

POSPÍŠIL, I. (2019a): Lev Tolstoj: Nezbytí maximalismu a chození proti proudu. In: L. N. Tolstoj: Anna Karenina. Městské divadlo Brno 2019, s. 13-37.

POSPÍŠIL, I. (2019b): Pečlivé čtení a invence aneb o Kunderovi jinak: co na to mladí kunderologové? <http://www.phil.muni.cz/journal/proudy/filologie/recenze/2019/2/ pospisil_peclive_cteni_aneb_o_kunderovi_jinak.php\#articleBegin >. [online]. [cit. 10. 4. 2020].

POSPÍŠIL, I. (2019c): Staronové pohledy: Lev Tolstoj dnešníma očima. Novaja rusistika, 2019, č. 1, s. 78-84.

TOLSTOJ, L. N. (1907): O Šekspire i o drame. Sankt-Peterburg.

VÁCLAVEK, B. (1934): Česká literatura XX. století: rytmus vývoje a stav. Praha.

ZENKIN, S. N. (2004): Russkaja teorija: 1920-1930-je gody. Materialy 10-ch Lotmanovskich čtenij. Moskva. 
